\title{
STRATEGI DAN PROSPEK PENGEMBANGAN JAMBU METE (Anacardium occidentale. L) KABUPATEN JEMBER
}

\author{
Bagus Putu Yudhia Kurniawan \\ Jurusan Manajemen Agribisnis, Politeknik Negeri Jember
}

\author{
E-mail: baguspyudhia@gmail.com \\ HP. +6281234560070
}

\begin{abstract}
The increasing growth of world cashew consumption is an opportunity for Indonesia and East Java province to increase cashew production. Cashew production on a national scale reached 95,000 tons per year. East Java province contributed about $11 \%$ of the national cashew production. Jember is famous as a center for cashew producer in the Eastern region of East Java province and has great potential in the development of agribusiness/agroindustry cashew nuts. However, they found some of problems that hamper the success of cashew farming. The purpose of this study is to formulate a strategy and analyze the development prospects for of cashew Jember Regency. The analysis technique used were Internal Factor Evaluation (IFE) matrix, External Factor Evaluation (EFE) matrix, Relative Competitive Position matrix, Internal and External (IE) matrix, and SWOT matrix. The results showed that internal factors are a major force in cashiew farming was cultivation techniques, while being the weakness was the production and marketing. External factors were the largest opportunity in the farming of cashew was the suitability of land and government policies, while the greatest threat is climate risks and uncertainties. The strategy recommended in the development of cashew Jember Regency is a growthoriented strategy through horizontal integration (concentration through horizontal integration) with strategic priorities: (1) improving farming techniques with input suitable productive land, quality seeds and adequate capital, so that the product cashew produced can be more qualified and have a more competitive price in the market; and (2) more consistently maintaining the quality of the product, so that the consumer confidence is also increasing.
\end{abstract}

Keywords : Strategy, Development Prospects, Cashew 


\section{PENDAHULUAN}

Jambu mete (Anacardium occidentale. L) merupakan salah satu komoditas unggulan tanaman perkebunan yang menjadi prioritas pemerintah dalam pembangunan ekonomi dan pertanian di masa depan. Jambu mete memiliki kontribusi cukup besar dalam perekonomian Indonesia, antara lain sebagai penghasil devisa negara, sumber pendapatan petani, penghasil bahan baku industri makanan, penciptaan lapangan kerja dan pengembangan wilayah.

Meningkatnya pertumbuhan konsumsi dunia, utamanya negara-negara di Amerika Utara, Uni Eropa, China, Timur Tengah, India dan Australia sebagai negara konsumen kacang mete dunia adalah salah satu peluang bagi Indonesia untuk meningkatkan produksi jambu mete. Indonesia merupakan negara produsen mete terbesar kelima dunia setelah India, Nigeria, Brazil, dan Tanzania. Produksi mete gelondongan Indonesia (mete yang belum dibuka cangkangnya/belum dikacip, cashews in-shell) setiap tahun mencapai 95 ribu ton dan hanya $20 \%$, yaitu sekitar 19 ribu ton yang disalurkan untuk kebutuhan dalam negeri (pasar domestik), sementara $80 \%$ lebihnya, yaitu sekitar 76 ribu ton di ekspor ke berbagai negara (CS Bisnis UKM 2009)

Produk mete gelondongan Indonesia diterima baik di berbagai pasaran dunia karena memiliki kualitas yang sudah terbukti. Indonesia adalah salah satu negara terbesar pengekspor mete gelondongan ke India, Vietnam, dan Brazil yang kemudian di negara itulah mete tersebut diolah menjadi kacang mete dan produk-produk turunannya (CS Bisnis UKM 2009).

Ekspor mete gelondongan memang cukup menggiurkan dari segi bisnis, hal ini dikarenakan: Pertama, kualitas mete gelondongan Indonesia lebih bagus dibandingkan dari Afrika, karena itu harganya berada di kisaran tertinggi (sekitar 775 U\$D per metrik ton). Kedua, musim panen jambu mete di Indonesia tidak bersamaan dengan musim panen negara produsen mete utama dunia (musim panen jambu mete di Vietnam, India dan Afrika berlangsung dari bulan Februari hingga April), sehingga mete gelondongan dari Indonesia memiliki daya saing yang tinggi. Ketiga, Indonesia, secara geografis relatif dekat dengan Vietnam dan India, sehingga proporsi biaya transportasi terhadap total harga penjualan akhir relatif rendah, yaitu hanya sekitar 7\%, jauh lebih rendah dibandingkan dengan mete dari Afrika Barat (Nigeria) yang biaya transportasinya bisa mencapai $40 \%$.

Produksi mete gelondongan dalam skala nasional berada di kisaran 95.000 ton per tahun. Dari hasil produksi tersebut, Provinsi Jawa Timur memberikan kontribusi sekitar $11 \%$ terhadap produksi mete nasional (Udin, S. 2013). Hal ini tentu saja menciptakan peluang bagi Provinsi Jawa Timur untuk menjadi pusat mete Indonesia, mengingat Jawa Timur merupakan provinsi yang mempunyai potensi besar dalam pengembangan agribisnis/agroindustri jambu mete.

Perkembangan areal untuk jambu mete di Jawa Timur dalam kurun waktu 2010-2014 mengalami peningkatan, yaitu 48.284 ha pada tahun 2010 meningkat menjadi 48.626 ha pada tahun 2014 dengan tingkat pertumbuhan rata-rata $1,78 \%$ per tahun. Perkembangan produksi jambu mete di Jawa Timur dalam kurun waktu 2010-2014 juga mengalami peningkatan, yaitu 10.500 ton pada tahun 2010 meningkat menjadi 12.849 ton pada tahun 2014 dengan tingkat pertumbuhan rata-rata mencapai 1,88\% per tahun. 
Jember merupakan kabupaten di daerah Tapal Kuda yang terletak di wilayah Timur Provinsi Jawa Timur. Kabupaten Jember sejak tahun 2012 sampai sekarang terkenal sebagai sentra penghasil jambu mete di wilayah Timur Provinsi Jawa Timur dan memiliki potensi besar dalam pengembangan agribisnis/agroindustri jambu mete. Kabupaten Jember memiliki areal lahan produktif untuk budidaya jambu mete seluas 280 ha dengan produksi rata-rata per tahun mencapai 160 ton.

Usahatani jambu mete di Kabupaten Jember telah memberikan penghidupan dan kesempatan kerja bagi sebagian besar petani, baik sebagai usaha sampingan maupun usaha pokok. Respon petani untuk menanam jambu mete sudah mulai baik karena usahatani jambu mete mempu memberikan pendapatan yang cukup berarti bagi petani sejalan dengan meningkatnya permintaan ekspor di samping pemeliharaan tanaman jambu mete relatif mudah. Namun demikian, di tingkat petani masih ditemukan berbagai permasalahan yang menghambat keberhasilan usahatani jambu mete.

Memaknai data resmi dari Badan Pusat Statitsik Provinsi Jawa Timur (2015) bahwa luasan areal untuk budidaya jambu mete di Jember dalam kurun waktu 2008-2014 dapat dikatakan tidak mengalami peningkatan. Demikian halnya dengan produksi mete per tahun pada kurun waktu yang sama juga belum menunjukkan peningkatan yang signifikan (produksi mete pada kurun waktu 2008-2014 cenderung fluktuatif).

Selain persoalan produksi dan produktivitas, beberapa permasalahan yang lain juga ditemukan, seperti mete yang dijual petani masih dalam bentuk gelondongan dan bukan dalam bentuk olahan (biji mete olahan, cashews kernels) dan kurang jelasnya jaringan pemasaran. Petani dan/atau pedagang mete Jember sulit untuk menembus jaringan pemasaran yang ada di daerah lain karena pihak-pihak yang terlibat dalam jaringan pemasaran tersebut dan tempat kegiatan berlangsung tidak diketahui. Tujuan penelitian ini adalah untuk merumuskan strategi dan menganalisis prospek pengembangan jambu mete Kabupaten Jember.

\section{LANDASAN TEORI Manajemen Strategi}

Pandangan akan pentingnya manajemen strategi, pada awal mulanya memang hanya berkembang di sektor privat. Hampir semua kegiatan manajemen strategidi abad itu difokuskan pada organisasi privat (Bryson 1995:5). Pemanfaatan manajemen strategike dalam organisasi sektor publik sendiri baru dimulai pada awal tahun 1980-an (Quinn 1980; Brucker dalam Bryson 1995:7). Sementara itu, Keban (1995:8) mengemukakan bahwa penerapan manajemen strategi sebagai strategic planning belum menjadi suatu tradisi bagi birokrasi. Sedangkan dalam rangka memberikan pelayanan kepada publik yang lebih baik di masa mendatang, tradisi strategic planning bagi birokrasi akan sangat bermanfaat terutama dalam memacu pola berfikir strategi mengenai apa misi utama birokrasi yang hendak dicapai, tujuan jangka panjang dan pendeknya, rencana-rencana strategi, dan rencana-rencana operasional, khususnya program-program dan proyeknya. Relevansi manajemen strategi bagi birokrasi kiranya telah menemukan momentumnya saat ini mengingat sifat interconnectedness di lingkungan birokrasi juga semakin mengemuka dari waktu ke waktu. 
Manajemen strategi diterapkan dalam bisnis atau badan usaha agar bisnis atau badan usaha berjalan dengan baik dalam mencapai tujuan yang telah ditetapkan. Dalam perkembangannya konsep mengenai manajemen strategi mengalami perkembangan yang cukup sifnifikan. Hal tersebut antara lain ditandai dengan berbagai definisi dari para ahli, yaitu:

Olsen dan Eadie (1982:4) mendefinisikan manajemen strategi sebagai upaya yang didisiplinkan untuk membuat keputusan dan tindakan penting yang membentuk dan memandu bagaimana menjadi organisasi (atau entintas lainnya), apa yang dikerjakan organisasi (atau entitas lainnya), dan mengapa organisasi (atau entitas lainnya) mengerjakan hal seperti itu. Manajemen strategi adalah untuk merencanakan suatu arah bagi perusahaan (Freeman 1995:52). Menurut Bryson dan Einsweiler dalam Bryson (1995:4), bahwa manajemen strategi adalah sekumpulan konsep, prosedur, dan alat, serta sebagian karena sifat khas praktik perencanaan sektor publik di tingkat lokal. Manajemen strategi menekankan pada pengamatan dan evaluasi peluang dan ancaman lingkungan dengan melihat kekuatan dan kelemahan perusahaan (Hunger et al 2003:4).

Menurut David, F.R. (2009:5), manajemen strategi yang bisa disebut juga perencanaan strategi adalah seni dan pengetahuan dalam merumuskan, mengimplementasikan serta mengevaluasi keputusan-keputusan lintas fungsional yang memampukan sebuah organisasi mancapai tujuannya. Manajemen strategi berfokus pada usaha untuk mengintegrasikan manajemen, pemasaran, keuangan atau akuntansi, produksi atau operasi, penelitian dan pengembangan, serta sistem informasi komputer untuk mencapai keberhasilan organisasional. Wheelen dan Hunger (2012:53) mengemukakan pendapat yang sama, bahwa manajemen strategi adalah sekumpulan keputusan manajerial dan aksi pengambilan keputusan jangka panjang di dalam perusahaan. Hal ini termasuk analisis lingkungan (lingkungan eksternal dan internal), formulasi strategi, implementasi strategi, serta evaluasi dan control.

Manajemen strategi adalah menggabungkan pola berfikir strategi dengan fungsi-fungsi manajemen, yaitu perencanaan, pelaksanaan, pengendalian dan evaluasi. Manajemen strategi adalah usaha manajerial menumbuhkembangkan kekuatan perusahaan untuk mengeksploitasi peluang bisnis yang muncul guna mencapai tujuan perusahaan yang telah ditetapkan sesuai dengan misi yang telah ditentukan. Pengertian ini juga mengandung implikasi bahwa perusahaan-perusahaan mengurangi kelemahannya, dan berusaha melakukan adaptasi dengan lingkungan bisnisnya. Tujuan manajemen strategi atau perencanaan strategi adalah menganalisis dan memanfaatkan setiap sumberdaya yang ada untuk menciptakan peluang-peluang baru yang kemudian disebut sebagai strategistrategi efektif bagi perusahaan atau organisasi demi terciptanya keunggulan bersaing, pencapaian tujuan perusahaan dan implementasi efektif kebijakan perusahaan.

Secara historis, manfaat utama manajemen strategi telah membantu organisasi memformulasikan strategi yang lebih baik dengan menggunakan pendekatan yang sistematik, logis dan rasional untuk pilihan strategi. Selain manfaat utama, manajemen strategi memiliki manfaat financial dan nonfinansial. Manfaat financial, organisasi yang menggunakan konsep manajemen strategi lebih menguntungkan dan berhasil dibandingkan organisasi lain yang tidak menggunakan. Perusahaan dengan kinerja tinggi tampaknya membuat keputusan yang dilatarbelakangi informasi yang lengkap dengan antisipasi yang baik tentang konsekuensi jangka pendek dan jangka panjang. Manfaat 
nonfinansial, manajemen strategi menawarkan manfaat lainnya seperti meningkatkan kesadaran atas ancaman eksternal, pemahaman yang lebih baik atas strategi pesaing, meningkatnya produktivitas karyawan, mengurangi keengganan untuk berubah, pengertian yang lebih baik atas hubungan antara kinerja dan penghargaan (Hokiman 2015 http://dokumen.tips/documents/karakteristik-manajemen-strategi.html) (09 Juli 2015)

Bryson (1995:66-68) mengemukakan empat pendekatan dasar untuk mengenali isu strategi, yaitu:

1. Pendekatan langsung (direct approach), meliputi jalan lurus dari ulasan terhadap mandat, misi dan SWOTs hingga identifikasi isu-isu strategi. Pendekatan langsung dapat bekerja di dunia yang pluralistis, partisan, terpolitisasi, dan relatif terfragmentasi di sebagian besar organisasi publik, sepanjang ada koalisi dominan yang cukup kuat dan cukup menarik untuk membuatnya bekerja.

2. Pendekatan tidak langsung (indirect approach), hampir sama dengan pendekatan langsung dan biasanya dilakukan bersama dengan pendekatan langsung, hanya tidak dibentuk tim khusus.

3. Pendekatan sasaran (goals approach), lebih sejalan dengan teori pendekatan konvensional, yang menetapkan bahwa organisasi harus menciptakan sasaran dan tujuan bagi dirinya sendiri dan kemudian mengembangkan strategi untuk mencapainya. Pendekatan ini dapat bekerja jika ada kesepakatan yang agak luas dan mendalam tentang sasaran dan tujuan organisasi, serta jika sasaran dan tujuan itu cukup terperinci dan spesifik untuk memandu pengembangan strategi.

4. Pendekatan visi keberhasilan (vision of success), di mana organisasi mengembangkan suatu gambar yang terbaik atau ideal mengenai dirinya sendiri di masa depan sebagai organisasi yang sangat berhasil memenuhi misinya. Pendekatan ini lebih mungkin bekerja dalam organisasi nirlaba ketimbang organisasi sektor publik.

Proses manajemen strategis atau perencanaan strategis menurut Bryson dan Roring (1987:10) meliputi delapan langkah, seperti ditunjukkan pada Gambar 1 berikut.

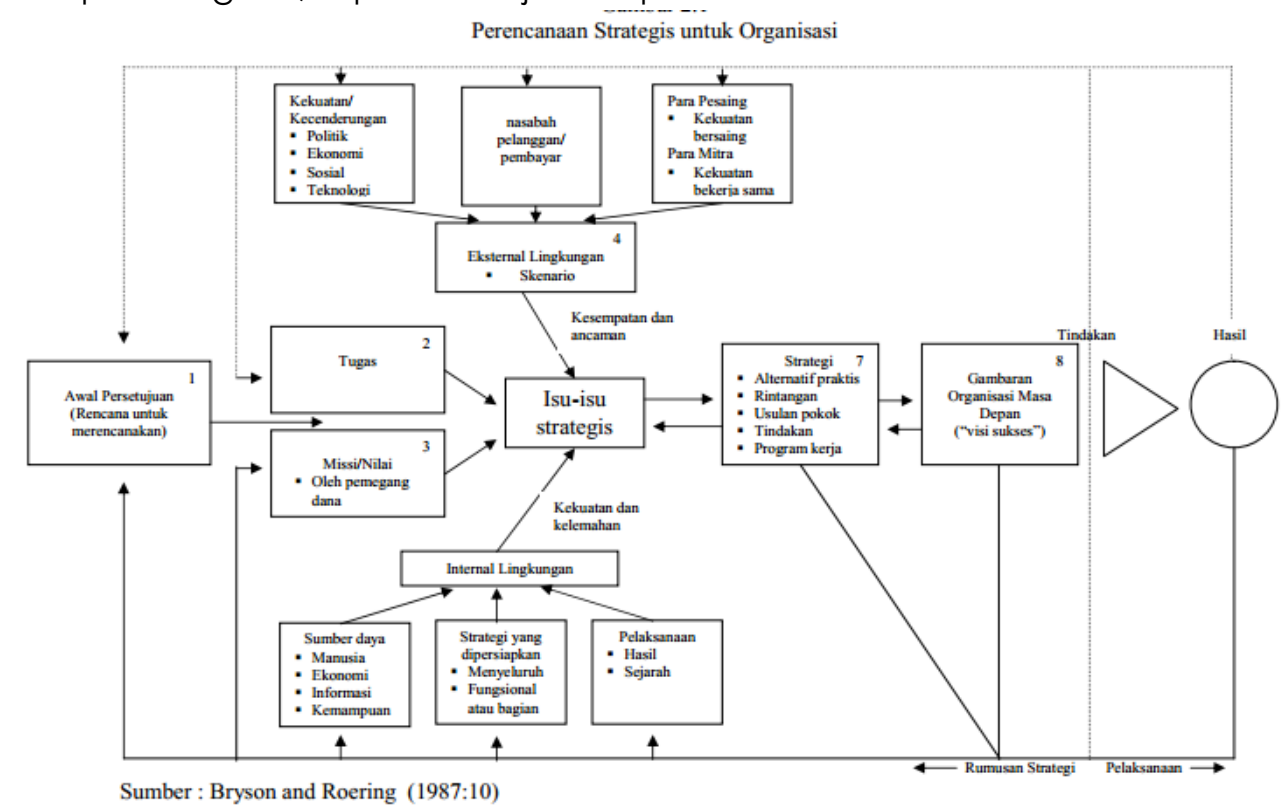

Gambar 1

Perencanaan Strategis untuk Organisasi Sumber: Bryson dan Roering 1987:10 
Berdasarkan model perencanaan strategi tersebut, sebagaimana yang dipaparkan Bryson dan Roering (1987:10), bahwa model tersebut menunjukkan hubungan antara komponenkomponen proses manajemen strategi sebagaimana dijelaskan dalam setiap tahaptahapnya sebagai berikut:

1. Memprakarsai dan menyepakati suatu proses perencanaan strategi. Tujuan langkah pertama adalah menegosiasikan kesepakatan dengan orang-orang penting pembuat keputusan (decision makers) atau pembentuk opini (opinion leaders) internal (dan mungkin eksternal) tentang seluruh upaya perencanaan strategi dan langkah perencanaan yang terpenting.

2. Mengidentifikasi mandat organisasi. Mandat formal dan informal yang ditempatkan pada organisasi adalah suatu keharusan yang dihadapi organisasi.

3. Memperjelas misi dan nilai-nilai organisasi. Misi organisasi yang berkaitan erat dengan mandatnya dan pembenaran sosial bagi keberadaannya.

4. Menilai lingkungan eksternal: peluang dan ancaman. Mengeksplorasi lingkungan di luar organisasi untuk mengidentifikasi peluang dan ancaman yang dihadapi oleh organisasi.

5. Menilai lingkungan internal: kekuatan dan kelemahan. Untuk mengenali kekuasaan dan kelemahan internal, organisasi dapat memantau sumberdaya (inputs), strategi sekarang (process), dan kinerja (outputs).

6. Mengidentifikasi isu strategi yang dihadapi organisasi. Isu strategi, meliputi konflik satu jenis atau lainnya. Konflik dapat menyangkut tujuan (apa), cara (bagaimana), filsafat (mengapa), tempat (dimana), waktu (kapan), dan kelompok yang mungkin diuntungkan atau tidak diuntungkan oleh cara-cara yang berbeda dalam pemecahan isu (siapa).

7. Merumuskan strategi untuk mengelola isu-isu. Strategi didefinisikan sebagai pola tujuan, kebijakan, program, tindakan, keputusan, atau alokasi sumberdaya yang menegaskan bagaimana organisasi, apa yang dikerjakan organisasi, mengapa organisasi harus melakukan hal tersebut.

8. Menciptakan visi organisasi yang efektif bagi masa depan. Langkah terakhir dari proses manajemen strategi adalah mengembangkan deskripsi mengenai bagaimana seharusnya organisasi itu sehingga berhasil mengimplementasikan strateginya dan mencapai seluruh potensinya

Menurut David, F.R. (2009:6), dalam perencanaan strategi terdapat tiga tahap penting yang tidak dapat dilewatkan oleh perusahaan ketika akan merencanakan strategi, yaitu formulasi strategi, implementasi/penerapan strategi, dan evaluasi strategi.

1. Formulasi strategi, yaitu tahap awal dimana perusahaan menetapkan visi dan misi disertai analisis mendalam terkait faktor internal dan eksternal perusahaan dan penetapan tujuan jangka panjang yang kemudian digunakan sebagai acuan untuk menciptakan alternatif strategi-strategi bisnis dimana akan dipilih salah satunya untuk ditetapkan sesuai dengan kondisi perusahaan.

2. Implementasi strategi, merupakan langkah dimana strategi yang telah melalui identifikasi ketat terkait faktor lingkungan eksternal dan internal serta penyesuaian tujuan perusahaan mulai diterapkan atau diimplementasikan dalam kebijakan-kebijakan intensif dimana setiap divisi dan fungsional perusahaan berkolaborasi dan bekerja sesuai dengan tugas dan kebijakannya masing-masing.

3. Evaluasi strategi, yaitu tahap akhir setelah strategi diterapkan dalam praktik nyata dinilai efektifitasnya terhadap ekspektasi dan pencapaian tujuan perusahaan. Penilaian dilakukan dengan mengukur faktor-faktor atau indikator sukses yang dicapai dan 
mengevaluasi keberhasilan kinerja dari strategi guna perumusan dan penerapan lanjutan di masa yang akan datang agar lebih baik dan efektif.

Tahapan-tahapan tersebut memiliki detil-detil aktivitas kunci yang akan memperjelas proses perencanaan strategi pada perusahaan, sebagaimana ditunjukkan pada model manajemen strategi komprehensif pada Gambar 2 berikut.

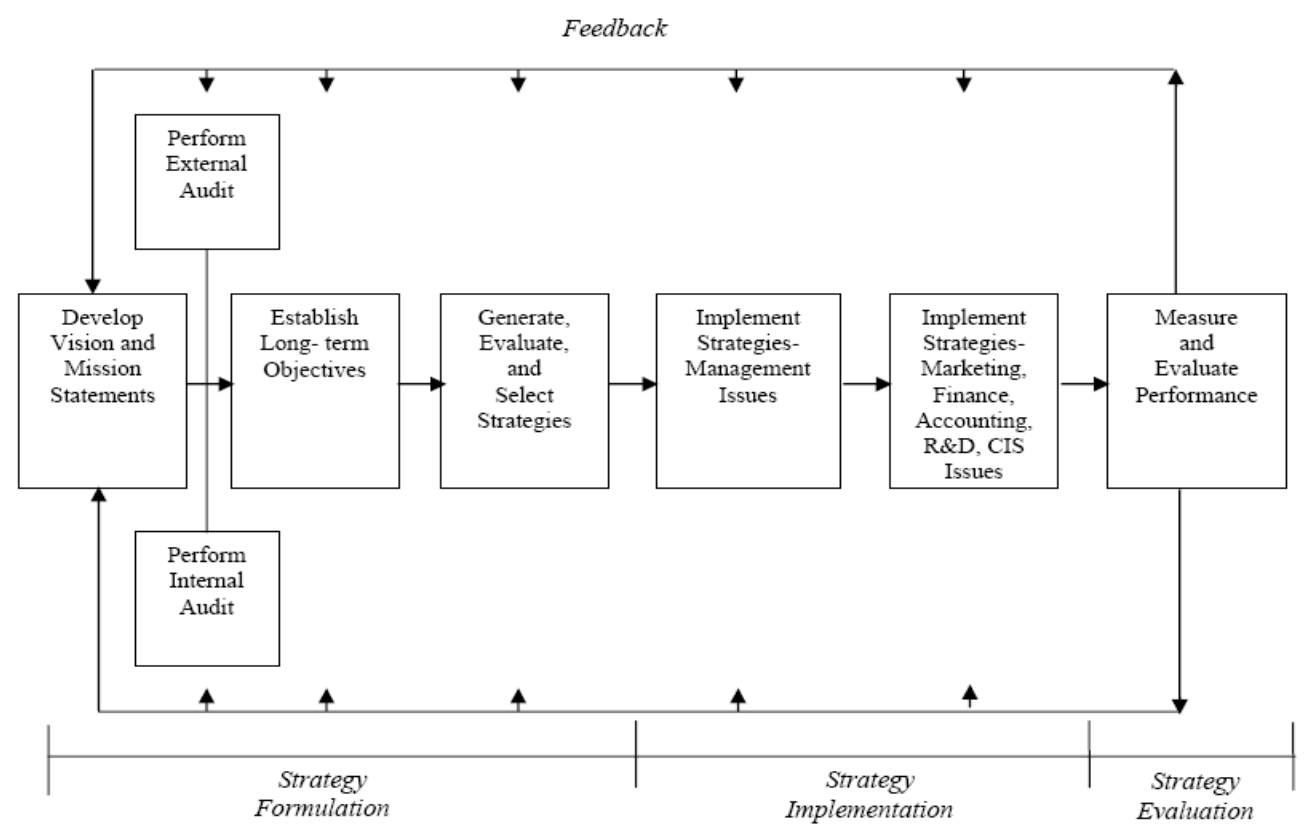

Gambar 2

Model Manajemen Strategi Komprehensif Sumber: David, F.R. 2009:21

Berdasarkan model manajemen strategi tersebut, sebagaimana yang dipaparkan David, F.R. (2009:21), bahwa model tersebut menunjukkan relasi antara komponen-komponen proses manajemen strategi rinci yang dapat diterima secara luas sehingga dapat dijelaskan dalam setiap tahap-tahapnya sebagai berikut:

1. Menetapkan Visi dan Misi, merupakan penetapan sasaran dan objektif jangka panjang (visi) serta menentukan langkah-langkah apa saja yang harus diambil untuk mempertegas dan memperjelas prioritas fungsi-fungsi tiap manajemen perusahaan agar pekerja, manajemen puncak, dan fungsional perusahaan dapat saling bersinergi dan berkolaborasi untuk mencapai visi sebagai tujuan yang telah ditentukan.

2. Analisis Lingkungan Eksternal dan Internal, yaitu analisis yang dilakukan oleh perusahaan terkait pemahaman mendalam tentang kondisi/keadaan internal dan eksternal perusahaan dengan cara mengenali secara jelas faktor-faktor berupa kekuatankelemahan dari internal perusahaan serta peluang-ancaman yang muncul dari lingkungan eksternal perusahaan. Analisis ini bertujuan melihat pengaruh yang akan muncul dari faktor-faktor tersebut terhadap sasaran atau tujuan perusahaan dan agar perusahaan dapat mempertimbangkan secara tepat kebijakan strategi yang akan digunakan.

3. Sasaran Jangka Panjang, yaitu pencapaian yang lebih dari satu tahun. Pada tahap ini, perusahaan menciptakan sinergi, menjelaskan prioritas, memfokuskan koordinasi dan 
menyediakan landasan bagi aktivitas perencanaan, pengorganisasian, pemotivasian, serta pengontrolan. Perusahaan juga membangun peramalan-peramalan khusus yang sistematis-kuantitatif, seperti estimasi penjualan, profitabilitas, peningkatan kinerja, dan lain-lain agar tujuan dan visi memiliki indikator yang jelas, terukur dan masuk akal.

4. Menciptakan, Menilai dan Memilih Strategi. Berbekal landasan visi dan misi, serta hasil analisis faktor-faktor lingkungan internal-eksternal, perusahaan merumuskan alternatif strategi-strategi yang sesuai dengan kapabilitas dan keadaan perusahaan diikuti dengan penilaian dan evaluasi kritis menggunakan penyesuaian objektif jangka panjang agar realisasi dari strategi tersebut dapat membawa hasil yang maksimal pada perusahaan dan selanjutnya strategi tersebutlah yang akan dipilih untuk direalisasikan.

5. Implementasi Strategi Manajemen Jangka Panjang, bahwa upaya pencapaian tujuan perusahaan merupakan suatu proses berkesinambungan yang memerlukan pentahapan spesifik. Pada tahap ini, perusahaan merealisasikan dengan bertahap sasaran jangka panjang tersebut dengan menetapkan standar pencapaian dan kebijakan strategi yang telah dipilih bagi setiap tingkat organisasi. Perusahaan menegaskan dan menentukan tujuan utamanya dalam nilai kuantitatif yang spesifik disertai pemaparan dan implementasi strategi yang digunakan oleh manajemen puncak, divisi dan fungsionalnya.

6. Implementasi Strategi dalam Kebijakan Fungsional, adalah langkah dimana perwujudan dari implementasi strategi diuraikan dalam langkah-langkah kecil dengan jangka waktu yang lebih pendek untuk diterapkan ke dalam fungsional perusahaan yang mana sifatnya lebih operasional dan mengarah berbagai bidang fungsional dalam perusahaan untuk memperjelas hubungan strategi utama dengan identifikasi rincian yang sifatnya spesifik. Implementasi ini mengaitkan segala bidang fungsional perusahaan seperti keuangan, sumberdaya manusia, produksi dan operasi, penelitian dan pengembangan, sistem informasi, serta bidang pemasaran yang menjadi penuntun dalam melakukan berbagai aktivitas agar konsisten bukan hanya dengan strategi utamanya saja.

7. Penilaian dan Evaluasi Kinerja. Ketika strategi yang akan ataupun telah diimplementasikan dinilai menunjukkan perubahan yang tidak sesuai dengan rencana yang ada, hasil yang dicapai, atau memang disebabkan asumsi yang salah dan oleh hal-hal lain yang sifatnya tidak dapat dikontrol, maka rencana perlu direvisi ulang dengan evaluasi kinerja. Tiga aktivitas penilaian strategi yang paling mendasar, yaitu peninjauan ulang faktor-faktor internal-eksternal yang menjadi landasan strategi saatini, pengukuran kinerja, dan pengambilan langkah korektif. Pengendalian melalui evaluasi dan penilaian berkala ditujukan agar program, kebijakan dan strategi yang diterapkan dapat berjalan sebagaimana mestinya sesuai dengan harapan perusahaan dan tanpa adanya penyimpangan.

\section{Analisis SWOT}

SWOT adalah sebuah analisis yang dicetuskan oleh Albert Humprey pada dasawarsa $1960-$ 1970an. Analisis SWOT berasal dari penelitian yang dilakukan di Stanford Research Institute 1960-1970. Latar belakang SWOT berasal dari kebutuhan untuk mencari tahu mengapa suatu perencanaan bisnis bisa gagal. Penelitian ini didanai oleh Fortune 500 untuk mengetahui apa yang bisa dilakukan tentang kegagalan ini. Tim Peneliti adalah Marion Dosher, Dr Otis Benepe, Albert Humphrey, Robert Stewart, dan Birger Lie. Analisis SWOT ini merupakan sebuah akronim dari huruf awalnya, yaitu Strengths (kekuatan), Weaknesses (kelemahan), Opportunities (peluang), dan Threats (ancaman). 
Analisis SWOT merupakan instrumen yang bermanfaat dalam melakukan analisis strategi. Analisis SWOT bisa dianggap sebagai metode analisis yang paling dasar yang berfungsi untuk mendapatkan informasi dari analisis situasi dan memisahkannya dalam pokok persoalan internal (kekuatan dan kelemahan) dan pokok persoalan eksternal (pelvang dan ancaman).

Analisis SWOT adalah evaluasi secara keseluruhan terhadap kekuatan, kelemahan, kesempatan dan ancaman yang dimiliki oleh perusahaan. Perusahaan harus menganalisis kekuatan perusahaan dan mengidentifikasi kelemahan perusahaan. Selain itu, perusahaan juga menganalisa pasar dan lingkungan pemasaran untuk mencari kesempatan yang atraktif dan mengidentifikasi ancaman. Tujuannya adalah untuk mencocokan kekuatan perusahaan dengan kesempatan yang ada dalam lingkungan di samping mengurangi kelemahan dan meminimalisasi ancaman yang dating (Kotler dan Armstrong 2008:50). Analisis SWOT digunakan untuk menilai kekuatan-kekuatan dan kelemahan-kelemahan dari sumber-sumber daya yang dimiliki perusahaan dan peluang-peluang eksternal dan ancaman-ancaman yang dihadapi (Jogiyanto 2005:46).

David, F.R. (2009:8) mengemukakan bahwa semua organisasi memiliki kekuatan dan kelemahan dalam area fungsional bisnis. Tidak ada perusahaan yang sama kuatnya atau lemahnya dalam semua area bisnis. Kekuatan/kelemahan internal, digabungkan dengan peluang/ancaman dari eksternal dan pernyataan misi yang jelas, menjadi dasar untuk penetapan tujuan dan strategi. Tujuan dan strategi ditetapkan dengan maksud memanfaatkan kekuatan internal dan mengatasi kelemahan.

David, F.R. (2009:17-18) mengemukakan penjelasan dari SWOT sebagai berikut: Pertama, Strengths (kekuatan), yaitu sumber daya, keterampilan, atau keunggulan-keunggulan lain yang berhubungan dengan para pesaing perusahaan dan kebutuhan pasar yang dapat dilayani oleh perusahaan yang diharapkan dapat dilayani. Kekuatan adalah kompetisi khusus yang memberikan keunggulan kompetitif bagi perusahaan di pasar. Kedua, Weaknesses (kelemahan), yaitu keterbatasan atau kekurangan dalam sumber daya, keterampilan, dan kapabilitas yang secara efektif menghambat kinerja perusahaan. Keterbatasan tersebut dapat berupa fasilitas, sumber daya keuangan, kemampuan manajemen dan keterampilan pemasaran yang merupakan sumber dari kelemahan perusahaan. Ketiga, Opportunities (peluang), yaitu situasi penting yang mengguntungkan dalam lingkungan perusahaan. Kecenderungan-kecenderungan penting merupakan salah satu sumber peluang, seperti perubahaan teknologi dan meningkatnya hubungan antara perusahaan dengan pembeli atau pemasok merupakan gambaran peluang bagi perusahaan. Keempat, Threats (ancaman), yaitu situasi penting yang tidak menguntungan dalam lingkungan perusahaan. Ancaman merupakan pengganggu utama bagi posisi sekarang atau yang diinginkan perusahaan. Adanya peraturan-peraturan pemerintah yang baru atau yang direvisi dapat merupakan ancaman bagi kesuksesan perusahaan.

Penyusunan strategi mengacu pada hasil analisis lingkungan eksternal dan internal yang kemudian dijadikan dasar untuk memilih strategi yang tepat (Hill dan Jones 2009:7). Keberhasilan strategi akan sangat bergantung pada kemampuan dan akurasi data analisis terhadap kondisi lingkungan internal dan eksternal perusahaan. Hasil analisis SWOT akan menghasilkan empat strategi, yaitu: Strategi so (Strengths-Opportunities), strategi ini 


\section{Bagus Putu Yudhia Kurniawan}

menggunakan kekuatan internal untuk memanfaatkan peluang eksternal. Strategi WO (Weaknesses-Opportunities), strategi ini memanfaatkan peluang eksternal dengan cara meminimalkan kelemahan internal yang ada. Strategi ST (Strengths-Threats), strategi ini menggunakan kekuatan internal untuk mengatasi ancaman eksternal. Strategi WT (Weaknesses-Threats) adalah strategi defensif yang diarahkan untuk mengurangi kelemahan internal dan menghindari ancaman eksternal.

\section{METODE PENELITIAN}

Lokasi penelitian ditentukan secara sengaja di Kabupaten Jember dengan pertimbangan bahwa Kabupaten Jember merupakan sentra penghasil jambu mete dan memiliki potensi besar dalam pengembangan agribisnis/agroindustri jambu mete di wilayah Timur Provinsi Jawa Timur. Namun demikian, di tingkat petani masih ditemukan berbagai permasalahan yang menghambat keberhasilan usahataninya, baik yang terkait dengan produksi dan produktivitas maupun pemasaran.

Penelitian ini termasuk dalam jenis penelitian survai. Penelitian ini merupakan penelitian studi kasus serta merupakan gabungan antara penelitian eksploratif, deskriptif dan explanatory. Penelitian eksploratif dilakukan untuk memperoleh informasi yang mendalam berkaitan dengan usahatani jambu mete, perumusan strategi pengembangan jambu mete Kabupaten Jember yang direkomendasikan serta prospek pengembangannya di masa akan datang melalui kajian teoritis dan empiris sebelum dilanjutkan dengan penelitian deskriptif.

Pengumpulan data primer dilakukan dengan wawancara langsung dan mendalam dengan sumber informasi atau informan ahli di bidangnya serta mengamati dokumen-dokumen yang ada. Pertanyaan yang diajukan telah disusun sebelumnya dengan sistematis dan dipandu dengan menggunakan kuesioner yang telah valid dan reliabel. Data sekunder bersumber dari informasi atau data yang dimiliki instansi terkait serta buku literatur, jurnal atau berbagai macam bentuk terbitan sebagaimana tertera dalam Daftar Pustaka.

Teknik pengambilan sampel dilakukan dengan metode tanpa peluang (non probability method), yaitu metode pengambilan sampel dengan sengaja (purposive sampling). Penentuan responden atau individu sasaran wawancara dipilih dan ditentukan secara sengaja berdasarkan pertimbangan pengetahuan, kemampuan dan pengalaman responden dalam bidang yang diteliti. Responden dipilih dari unsur pengambil kebijakan, petani yang dipandang representatif, pengepul, distributor, pemasok, dan tokoh masyarakat setempat.

Analisis data penelitian yang digunakan untuk merumuskan strategi pengembangan jambu mete Kabupaten Jember dan menganalisis prospek pengembangannya, secara berurutan, meliputi: Pertama, matrik Internal Factor Evaluation (IFE) yang digunakan untuk menganalisis faktor-faktor internal atas kekuatan dan kelemahan, kemudian dilakukan pembobotan. Kedua, matrik External Factor Evaluation (EFE) yang digunakan untuk menganalisis faktorfaktor eksternal atas peluang dan ancaman, kemudian dilakukan pembobotan. Ketiga, matrik Posisi Kompetitif Relatif yang didasarkan pada hasil perhitungan nilai IFE dan EFE. Keempat, matrik Internal dan Eksternal (IE) yang digunakan untuk menentukan posisi bisnis yang didasarkan pada analisis total skor faktor internal dan eksternal. Kelima, matrik SWOT yang digunakan untuk menentukan alternatif strategi, yaitu S-O, W-O, S-T dan W-T. 
Penentuan prioritas alternatif strategi yang dipilih, disesuaikan dengan posisi bisnis menurut hasil matrik Internal dan Eksternal (IE).

\section{HASIL DAN PEMBAHASAN}

Internal Factor Evaluation (IFE) dan External Factor Evaluation (EFE)

Analisis SWOT merupakan instrumen yang bermanfaat dalam melakukan analisis strategi. Pemanfaatan analisis SWOT didasarkan pada logika yang dapat memaksimalkan kekuatan dan peluang, namun secara bersamaan dapat meminimalkan kelemahan dan ancaman. Berdasarkan hasil penelitian, telah diidentifikasikan masing-masing faktor kekuatan, kelemahan, peluang, dan ancaman jambu mete Kabupaten Jember. Internal Factor Evaluation (IFE) dan External Factor Evaluation (EFE) jambu mete Jember secara berurutan masing-masing ditunjukkan pada Tabel 1 dan 2 berikut ini.

Tabel 1

Internal Factor Evaluation (IFE) Jambu Mete Kabupaten Jember

\begin{tabular}{|llccc|}
\hline No. & \multicolumn{1}{c}{ Faktor-faktor Internal } & Bobot & Rating & Nilai \\
\hline \multicolumn{1}{|c|}{ Kekuatan } & & & \\
\hline 1 & Teknik budidaya & 0.19 & 4 & 0.76 \\
\hline 2 & Kualitas produk & 0.14 & 3 & 0.42 \\
\hline 3 & Kualitas bibit & 0.14 & 3 & 0.42 \\
\hline 4 & Harga & 0.14 & 3 & 0.42 \\
\hline 5 & Modal & 0.09 & 2 & 0.18 \\
\hline & Jumlah (1) & $\mathbf{0 . 7 0}$ & $\mathbf{1 5}$ & $\mathbf{2 . 2 0}$ \\
\hline \multicolumn{2}{|c|}{ Kelemahan } & & & \\
\hline 1 & Produksi & 0.15 & 2 & 0.30 \\
\hline 2 & Pemasaran & 0.15 & 2 & 0.30 \\
\hline & Jumlah (2) & $\mathbf{0 . 3 0}$ & $\mathbf{4}$ & $\mathbf{0 . 6 0}$ \\
\hline & Total (1) + (2) & $\mathbf{1 . 0 0}$ & & $\mathbf{2 , 8 0}$ \\
\hline
\end{tabular}

Tabel 2

External Factor Evaluation (EFE) Jambu Mete Kabupaten Jember

\begin{tabular}{|c|c|c|c|c|}
\hline No. & Faktor-faktor Eksternal & Bobot & Rating & Nilai \\
\hline \multicolumn{5}{|c|}{ Peluang } \\
\hline 1 & Kesesuaian lahan & 0.19 & 4 & 0.76 \\
\hline 2 & Kebijakan pemerintah & 0.19 & 4 & 0.76 \\
\hline 3 & Dukungan kelompok & 0.14 & 3 & 0.42 \\
\hline 4 & Kepercayaan konsumen & 0.05 & 1 & 0.05 \\
\hline 5 & Sarana transportasi & 0.14 & 3 & 0.42 \\
\hline & Jumlah (1) & 0.71 & 15 & 2.41 \\
\hline \multicolumn{5}{|c|}{ Ancaman } \\
\hline 1 & Resiko dan ketidakpastian Iklim & 0.21 & 3 & 0.63 \\
\hline 2 & Persaingan pasar & 0.07 & 1 & 0.07 \\
\hline & Jumlah (2) & 0.28 & 4 & 0.70 \\
\hline & Total $(1)+(2)$ & 0,99 & & 3,11 \\
\hline
\end{tabular}

Tabel 1 menunjukkan bahwa faktor internal yang menjadi kekuatan usahatani jambu mete Kabupaten Jember dengan rating atau peringkat tertinggi (nilai peringkat 4) dan bobot tertinggi (nilai bobot 0,19 atau 19\%) adalah teknik budidaya. Hasil ini menunjukkan bahwa 


\section{Bagus Putu Yudhia Kurniawan}

teknik budidaya merupakan faktor internal yang menjadi kekuatan utama atau dianggap paling penting dalam usahatani jambu mete. Faktor internal yang menjadi kelemahan usahatani jambu mete Kabupaten Jember dengan rating atau peringkat tertinggi (nilai peringkat 2) dan bobot tertinggi (nilai bobot 0,15 atau 15\%) adalah produksi dan pemasaran. Hasil ini menunjukkan bahwa produksi dan pemasaran merupakan faktor internal yang menjadi kelemahan utama dan harus menjadi prioritas utama untuk diatasi dalam usahatani jambu mete.

Tabel 2 juga menunjukkan bahwa faktor eksternal yang menjadi peluang usahatani jambu mete Kabupaten Jember dengan rating atau peringkat tertinggi (nilai peringkat 4) dan bobot tertinggi (nilai bobot 0,19 atau 19\%) adalah kesesuaian lahan dan kebijakan pemerintah. Hasil ini menunjukkan bahwa kesesuaian lahan dan kebijakan pemerintah merupakan faktor eksternal yang menjadi peluang terbesar dalam usahatani jambu mete. Hal ini sesuai dengan kebijakan pemerintah, yang beberapa tahun terakhir ini menempatkan pasar internasional (ekspor) sebagai prioritas utama dalam implementasi strategi pemasaran jambu mete Kabupaten Jember. Faktor eksternal yang menjadi ancaman jambu mete Kabupaten Jember dengan rating atau peringkat tertinggi (nilai peringkat 3) dan bobot tertinggi (nilai bobot 0,21 atau 21\%) adalah resiko dan ketidakpastian iklim. Hasil ini menunjukkan bahwa resiko dan ketidakpastian iklim merupakan faktor eksternal yang menjadi ancaman terbesar dan menjadi prioritas utama untuk diantisipasi dalam usahatani jambu mete.

\section{Matrik Posisi Kompetitif Relatif}

Hasil perhitungan nilai faktor-faktor internal dan eksternal pada usahatani jambu mete Kabupaten Jember dapat dikompilasikan ke dalam matriks posisi kompetitif relatif. Diagram matrik posisi kompetitif relatif usahatani jambu mete Kabupaten Jember ditunjukkan pada Gambar 1 berikut ini. 


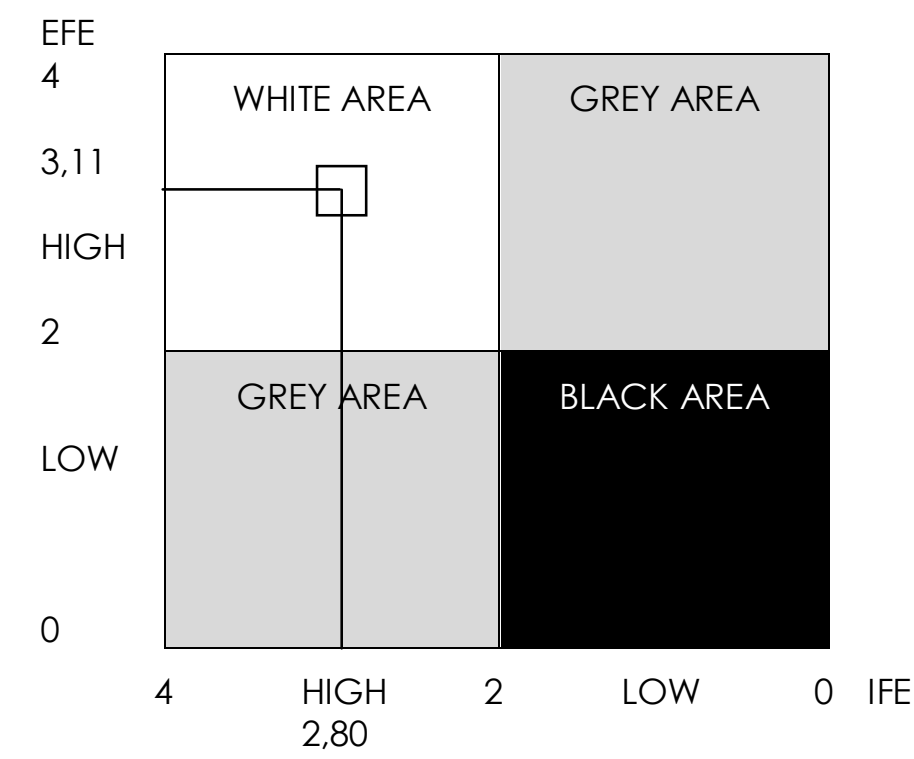

\section{Gambar 1 \\ Diagram Matriks Posisi Kompetitif Relatif Usahatani Jambu Mete Kabupaten Jember}

Gambar 1 menunjukkan bahwa usahatani jambu mete Kabupaten Jember berada pada posisi White Area (Kuat - Berpeluang) dengan nilai faktor-faktor internal (IFE) dan eksternal (EFE) secara berurutan masing-masing sebesar 2,80 dan 3,11. White Area merupakan posisi yang paling menguntungkan bagi usahatani jambu mete Kabupaten Jember karena pada kondisi ini memiliki banyak kekuatan dan peluang yang besar yang dapat dimanfaatkan untuk mengembangkan usahataninya. Strategi yang perlu dilakukan dalam kondisi ini adalah mendukung kebijakan pertumbuhan yang agresif atau growth oriented strategy, yang berarti berkaitan erat dengan langkah atau strategi yang ditempuh untuk melakukan pertumbuhan dan perkembangan dari usahatani jambu mete tersebut, yaitu:

1. Strategi konsentrasi, kegiatan untuk melakukan peningkatan kualitas produk mete yang dihasilkan.

2. Strategi perluasan/pengembangan pasar, menemukan pasar baru bagi produk mete yang dihasilkan saat ini.

3. Strategi diversifikasi produk, dilakukan dengan cara mengembangkan produk baru untuk tujuan memenuhi kebutuhan pasar yang baru. Ini berarti mete tidak lagi dijual gelondongan (mete yang belum dibuka cangkangnya/belum dikacip, cashews in-shell) namun dijual setelah menjadi kacang mete (biji mete olahan, cashews kernels) dan/atau produk-produk turunannya, sehingga dapat meningkatkan nilai tambah dan nilai jual mete yang dihasilkan. 


\section{Bagus Putu Yudhia Kurniawan}

\section{Matrik Internal Eksternal (IE)}

Internal dan Eksternal (IE) digunakan untuk menentukan posisi bisnis yang didasarkan pada analisis total skor faktor internal dan eksternal. Diagram matrik internal dan eksternal usahatani jambu mete Kabupaten Jember ditunjukkan pada Gambar 2 berikut ini.

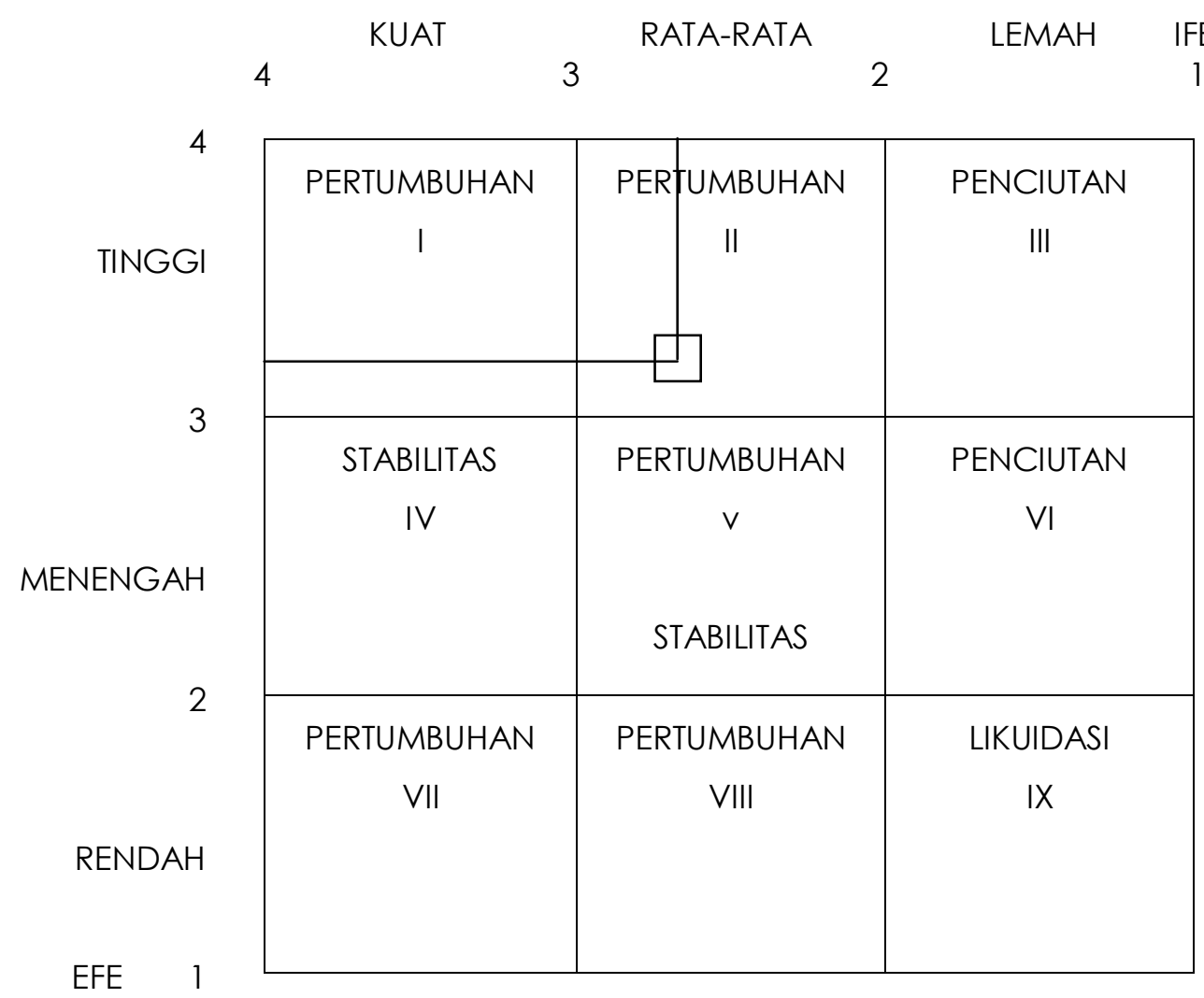

\section{Gambar 2}

Matriks Internal Eksternal (IE) Usahatani Jambu Mete Kabupaten Jember

Gambar 2 menunjukkan bahwa usahatani jambu mete Kabupaten Jember berada pada daerah Pertumbuhan II. Pada Daerah II, strategi pertumbuhan dapat dicapai melalui integrasi horizontal (konsentrasi melalui integrasi horizontal). Integrasi horizontal yang dimaksud dalam penelitian ini adalah suatu kegiatan untuk mengembangkan usahatani jambu mete dengan dengan cara membangun bisnis di lokasi atau hamparan luasan yang lain atau meningkatkan jenis produk. Integrasi horizontal dapat pula dilakukan dengan memperluas atau mengembangkan pasar, meningkatkan fasilitas produksi dan teknologi melalui akuisisi atau joint ventures dengan perusahaan lain dalam industri yang sama, serta memanfatkan keuntungan economics of scale, baik di produksi maupun pemasaran. 


\section{Matrik SWOT}

Alternatif strategi pengembangan jambu mete Kabupaten Jember yang dapat direkomendasikan, ditunjukkan pada matrik SWOT pada Gambar 3 berikut ini.

\begin{tabular}{|c|c|c|}
\hline IFE & Kekuatan (S) & Kelemahan (W) \\
\hline EFE & $\begin{array}{l}\text { 1. Teknik budidaya } \\
\text { 2. Kualitas produk } \\
\text { 3. Kualitas bibit } \\
\text { 4. Harga } \\
\text { 5. Modal }\end{array}$ & $\begin{array}{ll}\text { 1. } & \text { Produksi } \\
\text { 2. } & \text { Pemasaran }\end{array}$ \\
\hline Peluang (O) & Strategi S-O & Strategi W-O \\
\hline $\begin{array}{l}\text { 1. Kesesuaian lahan } \\
\text { 2. Kebijakan pemerintah } \\
\text { 3. Dukungan kelompok } \\
\text { 4. Kepercayaan konsumen } \\
\text { 5. Sarana tranportasi }\end{array}$ & $\begin{array}{l}\text { 1. Petani dapat lebih } \\
\text { meningkatkan teknik } \\
\text { budidaya dengan input } \\
\text { lahan, bibit, dan modal } \\
\text { yang memadai } \\
\text { sehingga produk yang } \\
\text { dihasilkan dapat lebih } \\
\text { bermutu dan memiliki } \\
\text { harga yang lebih } \\
\text { kompetitif di pasar } \\
\text { 2. Petani dapat lebih } \\
\text { konsisten } \\
\text { mempertahankan } \\
\text { kualitas produk } \\
\text { sehingga kepercayaan } \\
\text { konsumen juga semakin } \\
\text { meningkat }\end{array}$ & $\begin{array}{l}\text { 1. Petani dapat } \\
\text { meningkatkan hasil } \\
\text { produksinya dengan } \\
\text { memanfaatkan lahan } \\
\text { produktif yang tersedia } \\
\text { dan dukungan } \\
\text { kelompok } \\
\text { 2. Petani dapat } \\
\text { meningkatkan akses ke } \\
\text { pasar yang lebih luas } \\
\text { dengan sarana } \\
\text { tranportasi yang } \\
\text { memadai dan } \\
\text { dukungan kelompok }\end{array}$ \\
\hline Ancaman (T) & Strategi S-T & Strategi W-T \\
\hline $\begin{array}{l}\text { 1. Resiko dan } \\
\text { ketidakpastian } \\
\text { 2. Persaingan pasar }\end{array}$ & $\begin{array}{l}\text { 1. Petani dapat } \\
\text { meningkatkan teknik } \\
\text { budidaya sehingga } \\
\text { produk yang dihasilkan } \\
\text { dapat lebih bermutu } \\
\text { dan memiliki } \\
\text { keunggulan kompetitif } \\
\text { di pasar }\end{array}$ & $\begin{array}{l}\text { 1. Petani lebih intensif } \\
\text { dalam mengikuti } \\
\text { kegiatan-kegiatan } \\
\text { pembinaan yang } \\
\text { diadakan pemerintah } \\
\text { 2. Petani dapat } \\
\text { meningkatkan kinerja } \\
\text { promosi agar produknya } \\
\text { lebih dikenal di pasar }\end{array}$ \\
\hline
\end{tabular}

\section{Gambar 3}

Matrik SWOT Pengembangan Jambu Mete Kabupaten Jember

Gambar 3 menunjukkan hasil analisis SWOT yang menghasilkan empat strategi, yaitu: (1) strategi SO, yaitu menggunakan kekuatan internal untuk memanfaatkan peluang eksternal; (2) strategi WO, yaitu memanfaatkan peluang eksternal dengan cara meminimalkan kelemahan internal yang ada; (3) strategi ST, yaitu menggunakan kekuatan internal untuk mengatasi ancaman eksternal; dan (4) strategi WT, strategi defensif yang diarahkan untuk mengurangi kelemahan internal dan menghindari ancaman eksternal. Keempat strategi yang dihasilkan analisis SWOT ini, salah satunya merupakan strategi utama dan tiga lainnya merupakan strategi alternatif.

Strategi utama dipilih berdasarkan hasil penilaian terhadap faktor-faktor internal (IFE) dan eksternal (EFE) (Tabel 1 dan 2), matrik Posisi Kompetitif Relatif yang didasarkan pada hasil perhitungan nilai IFE dan EFE (Gambar 1), dan matrik Internal dan Eksternal (IE) (Gambar 2) 
yang digunakan untuk menentukan posisi bisnis yang didasarkan pada analisis total skor faktor internal dan eksternal. Dengan demikian strategi utama yang direkomendasikan untuk mengembangkan usahatani jambu mete Kabupaten Jember adalah Strategi SO (StrengthsOpportunities), yaitu:

1. Petani dapat lebih meningkatkan teknik budidaya dengan input lahan produktif yang sesuai, bibit yang berkualitas, dan modal yang memadai sehingga produk mete yang dihasilkan dapat lebih bermutu dan memiliki harga yang lebih kompetitif di pasar.

2. Petani dapat lebih konsisten mempertahankan kualitas produk sehingga kepercayaan konsumen juga semakin meningkat.

\section{SIMPULAN DAN SARAN}

\section{Simpulan}

1. Faktor internal yang menjadi kekuatan utama atau dianggap paling penting dalam usahatani jambu mete adalah teknik budidaya. Faktor internal yang menjadi kelemahan utama dan harus menjadi prioritas utama untuk diatasi dalam usahatani jambu mete adalah produksi dan pemasaran. Faktor eksternal yang menjadi peluang terbesar dalam usahatani jambu mete adalah kesesuaian lahan dan kebijakan pemerintah. Faktor eksternal yang menjadi ancaman terbesar dan menjadi prioritas utama untuk diantisipasi dalam usahatani jambu mete adalah adalah resiko dan ketidakpastian iklim.

2. Berdasarkan diagram matriks posisi kompetitif relatif, usahatani jambu mete Kabupaten Jember berada pada posisi White Area (Kuat - Berpeluang). Strategi yang perlu dilakukan dalam kondisi ini adalah mendukung kebijakan pertumbuhan yang agresif atau growth oriented strategy.

3. Berdasarkan matrik internal eksternal (IE), usahatani jambu mete Kabupaten Jember berada pada daerah Pertumbuhan II. Strategi pertumbuhan dapat dicapai melalui integrasi horizontal (konsentrasi melalui integrasi horizontal).

4. Berdasarkan hasil analisis SWOT, maka strategi yang direkomendasikan untuk mengembangkan usahatani jambu mete Kabupaten Jember adalah Strategi SO (Strengths-Opportunities), yaitu: (a) meningkatkan teknik budidaya dengan input lahan produktif yang sesuai, bibit yang berkualitas, dan modal yang memadai sehingga produk mete yang dihasilkan dapat lebih bermutu dan memiliki harga yang lebih kompetitif di pasar; (b) Lebih konsisten mempertahankan kualitas produk sehingga kepercayaan konsumen juga semakin meningkat.

\section{Saran}

1. Perlu dilakukan kajian dengan ruang lingkup penelitian yang lebih luas serta kajian yang lebih mendetail untuk memperoleh jawaban yang lebih komprehensif mengenai kebijakan strategi pertumbuhan yang agresif (growth oriented strategy)

2. Perlu penelitian lebih lanjut dan mendalam pada setiap alternatif strategi dan prioritas strategi yang telah direkomendasikan untuk memberikan strategi terbaik dalam pengembangan agribisnis/agroindustri jambu mete Kabupaten Jember.

\section{DAFTAR REFERENSI}

Bryson, J. M., \& Roering, W. D. 1987. Applying Private Sector Strategic Planning to The Public Sector. Journal of the American Planning Association, , 53(1).10.

Bryson, John.M. 1995. Strategic Planning for Public and Nonprofit Organizations. A Guide to Strengthening and Sustaining Organizational Achievement. Revised Edition: San Francisco. Jossey-Bass Publisher. 
CS Bisnis UKM. 2009. Indonesia Mengekspor Mete Terbesar. http://bisnisukm.com/indonesiapengekspor-mete-terbesar.html (05 Maret 2009) (Diakses tanggal 21 Januari 2016).

David, F. R. 2009. Manajemen strategis - Konsep (Buku 1 Edisi 12). Jakarta: Salemba Empat.

Dinas Perkebunan Provinsi Jawa Timur. 2015. Luas Areal dan Produksi Tanaman Perkebunan. http://disbun.jatimprov.go.id/arealtanaman.php (updated tanggal 10 Juni 2015) (diakses tanggal 09 februari 2016).

Freeman, R. Edward, 1995, Manajemen Strategik, Jakarta: Pustaka Binaman Pressindo

Hunger, David K. dan Thomas L. Wheelen. 2003. Manajemen Strategis. Yogyakarta: ANDI.

Jogiyanto, H.M., 2005, Analisa dan Desain Sistem Informasi: Pendekatan Terstruktur Teori dan Praktik Aplikasi Bisnis, Yogyakarta: ANDI

Keban, Yeremias T. 1995. Indikator Kinerja Pemda: Pendekatan Manajemen dan Kebijakan, Yogyakarta: Fakultas IImU Sosial dan Politik UGM.

Olsen dan Eadie dalam Sarah. 2011. Memahami Dinamika Perencanaan Strategis. http://sarahhifis29.blogspot.co.id/2011/06/memahami-dinamika-perencanaanstrategis.html (12 Juni 2011) (diakses tanggal 09 februari 2016)

Pearce, J.A. dan R.B. Robinson. 1997. Manajemen Strategik: Formulasi, Implementasi dan Pengendalian. Jakarta: Bina Rupa Aksara.

Purwanto, E. Perdagangan Mete, Kesejahteraan Petani, dan Pelestarian Lingkungan. https://epurwanto.wordpress.com/perdagangan-mete-kesejahteraan-petani-danpelestarian-lingkungan-2/ (Diakses tanggal 21 Januari 2016).

Quinn, J.B. 1980. Strategies for Change. Homewood, IL: Richard Irwin

Udin, $\quad 2013.2$ Jatim Genjot Produksi Mete. http://yayasanjambumete.blogspot.co.id/2013/02/jatim-genjot-produksi-mete.html l05 Februari 2013) (Diakses tanggal 19 Januari 2016).

Wheelen, T.L. dan Hunger, J.D. 2012. Concepts in Strategic Management and Business Policy. $13^{\text {th }}$ (International) ed., Upper Saddle River, NJ: Pearson 